\title{
Postoperative Wound Infection
}

National Cancer Institute

\section{Source}

National Cancer Institute. Postoperative Wound Infection. NCI Thesaurus. Code C50704.

Infection of a surgical skin incision. 